\title{
How to Improve Employee Performance at Level 1 Health Facilities During the Covid 19 Pandemic?
}

\author{
Nurul Qomariah $^{1 *}$, Haris Hermawan ${ }^{2}$, Nurul Habibatus Isnaini ${ }^{3}$, M Naely Azhad ${ }^{4}$ \\ ${ }^{1234}$ Universitas Muhammadiyah Jember, Jalan Karimata 49 Jember 68121 Jawa Timur Indonesia.
}

Orchid id: 0000-0001-8662-8904

\begin{abstract}
The role of health facilities in the form of hospitals, health centers and other health facilities was very important when the Covid 19 pandemic hit Indonesia in particular and the world in general. Healthy society, the country will be strong. Health is one part that cannot be separated from the national development of a country. This study aims to determine the effect of work motivation, leadership style and the application of work culture to the performance of employee at Tegalsari Public Health Center, Banyuwangi Regency. The population in this study were all employees at Tegalsari Public Health Center, Banyuwangi Regency, totaling 75 employees, all of whom were used as research samples. This study uses a questionnaire measuring tool, so it requires a validity test and a reliability test. Multiple linear regression analysis was used to determine the effect of independent variables on the dependent variable using SPSS. The classical assumption test is carried out to assess whether there are problems with classical assumptions in the Ordinary Least Square (OLS) linear regression model. The results showed that work motivation (0.177) had an effect on employee' performance. Leadership Style (0.282) affects the performance of employee. Work culture (-0.027) does not affect the performance of erawat at Tegalsari Health Center Banyuwangi.
\end{abstract}

Keywords: work motivation, leadership style, work culture, employee performance, Puskesmas.

\section{INTRODUCTION}

The role of health facilities is very important for society today with the existence of government policies related to BPJS Kesehatan (Health Social Security Administering Bodies) especially when the Covid 19 Pandemic hit Indonesia and even around the world. The existing health facilities that can provide services to the community consist of: Level 1 health facilities which include health centers, clinics, medical practices, dental practices, and class D hospitals. Level 2 health facilities are advanced level 1 health facilities with referrals hospitals class $\mathrm{C}$ and B. Level 3 health facilities which include class A hospitals with more complete facilities and infrastructure. The role of this health facility is very important in helping the community in dealing with some of the diseases they suffer, especially when the Covid 19 pandemic has hit all of Indonesia in particular and the world in general.
Figure 1 shows the development of the number of existing facilities in Indonesia from 2014 to 2018. The number of health facilities has grown significantly since the government implemented BPJS Kesehatan in 2014 (Anon 2019). However, the number of existing health facilities is still considered insufficient in dealing with patients who are seeking treatment and this is also added to the condition of the Covid 19 Pandemic that is currently sweeping around the world. In addition, there are still many patients from Indonesia who are still happy to seek medical treatment abroad, such as Malaysia and Singapore. In the current conditions where the Covid 19 pandemic is striking, all health facilities are required to provide maximum service to all patients who are going for treatment. Satisfactory health services from existing health facilities indicate that all aspects of health facilities, both medical devices, human resources that handle patients, are all deployed with the hope that health facilities have a good performance. The aspect of human resources in health facilities which can also be said to be health workers has a very important role in providing healing and safety to patients who seek treatment. . This is because patient safety and recovery are the most important indicators in determining how much quality is a consideration in a health facility in the form of a hospital or public health center. This has been determined since 2012 by the Hospital Accreditation Commission (KARS). The Hospital Accreditation Commission (KARS) has become a patient safety movement as the basis and accreditation standard for hospitals with the preparation of patient safety guidelines by the Hospital Accreditation Commission (KARS) (Ministry of Health, 2006)

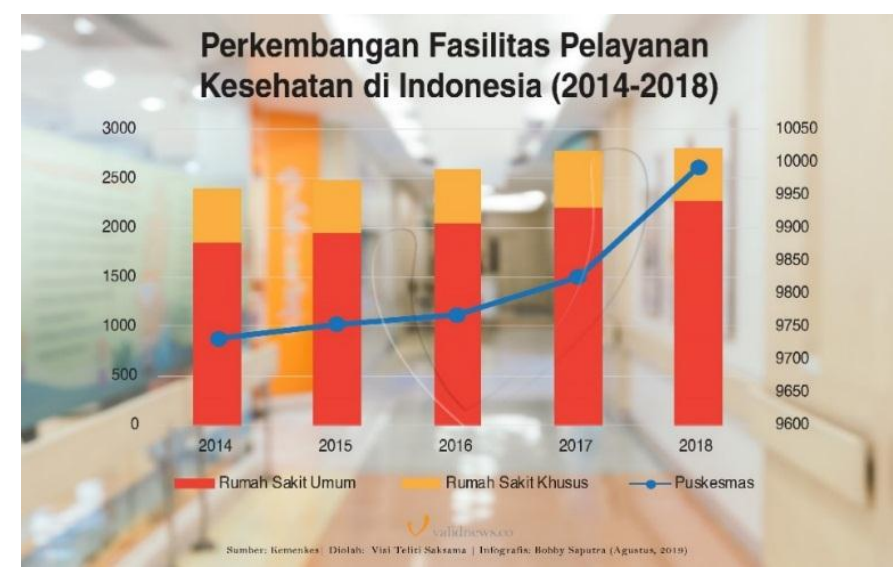

Figure 1. Number of Development of Health Facilities 2014-2018 
The Covid 19 pandemic outbreak has yet to be predicted when it will end, therefore the government and society must work together in overcoming the Covid 19 problem. Currently the Covid 19 pandemic cases in Indonesia have reached 225,030 cases (Anon 2020). With the increasing number of cases indicated by Covid 19, all parties such as the government, health assistance and the public must continue to be vigilant in dealing with this problem. Health facilities have a very important role because they are an inseparable part of national development. Therefore, the human resources involved in existing health facilities must continue to improve organizational performance by increasing the performance of health workers who in this case can be said to be employees. The performance of these employee is important to note considering that health is the main key for a nation in order to carry out development.

Employee performance is the work achieved by an employee in achieving goals based on standardization or measurement with time adjusted to the type of work and in accordance with the norms and ethics set by the company or organization (Ruky 2006). One's efforts in carrying out the tasks given by the leadership (Nawawi 2011). Many factors can improve an employee's performance, including work motivation, leadership style and work culture.

The first factor that can improve employee performance is work motivation. Work motivation is the driving force that moves a person to be able to work even harder (Azhad, Anwar, and Qomariah 2015).The theory expressed by Maslow states that there are 5 hierarchies of needs that can encourage or motivate a person to work, namely the need for physiology, the need for security, the need for a sense of belonging, the need for appreciation and the need for self-actualization (Sutrisno 2015). A person's work motivation if it is related to performance will be very related. A person's work motivation because they want to get an award will make someone work even harder until the award they get is obtained. With someone's active work, it will automatically increase the performance that must be achieved.

Many studies have been conducted that link work motivation to employee performance. Research (Ahmad, Talib, and Tiro 2014) on the Guidance and Counseling Teachers of Public Senior High Schools in South Sulawesi with a total sample of 163 teachers stated that work motivation can improve teacher performance. Research (Basalamah 2017) on SEGWAY employees at the Makassar City Government which consists of a Secretariat, the result is that motivation can improve the performance of civil servants. Research (Priyono, Qomariah, and Pawestri Winahyu 2018) on teachers of SMAN 1 Tanggul Jember with a total of 40 teachers as respondents stated that leadership style, teacher motivation and physical work environment have an impact on teacher performance. Research (Utomo et al., 2019) on hospital staff dr. Soebandi Jember with 226 nurses as respondents stated that there was a positive relationship between motivation and nurse performance. (Hendrawijaya, Imsiyah, and Indrianti 2019) conducted research with the theme of motivation and performance on archers in Malaysia, the result is that motivation can improve the performance of archer athletes. Research (Hidayah and Tobing 2018) with the theme of motivation, job satisfaction, organizational commitment and employee performance with a sample of 50 respondents. The result is that motivation has an impact on employee performance at STIE Mandala Jember. (Permana et al. 2019) conducted research with the theme leadership style, motivation, discipline and performance of employee at Koperasi Simpan Pinjam Sejahtera Bersama. The number of samples in this study were 97 respondents. The results showed that leadership style, work motivation and work discipline had an impact on employee performance. (Soebyakto, Hanafi, and Rakasiwih 2019) conducted research at PT Techwin BKT. The number of respondents was $55 \mathrm{em}-$ ployees. The analysis tool uses PLS and the results of the study show that work motivation has an effect on employee performance. (Istanti et al. 2020) conducted research with the theme of motivation, work milieu, and organizational commitment as well as teacher performance at Madrasah Tsanawiyah (MTS) Negeri 4 Surabaya with a total sample of 56 respondents. The results of the analysis show that there is a significant influence between motivation, work milieu, and organizational commitment to employees. (Ardianti, Qomariah, and Wibowo 2018) conducted research at PT. Sumber Alam Santoso Pratama Karangsari Banyuwangi with the theme of work motivation, compensation and work environment and employee job satisfaction. With a sample size of 46 employees the result is that work motivation, work compensation and work environment have a significant effect on employee job satisfaction with a determination coefficient of 70.5\%. (Sari, Qomariah, and Setyowati 2020) conducted research on Aston Jember Hotel employees with research themes namely the role of emotional intelligence, spiritual intelligence and work motivation and employee performance with 50 employees as respondents. The results showed that work motivation has a significant effect on employee performance. (Kurniawan, Qomariah, and Winahyu 2019) conducted research on 61 employees at PTPN XII Glantang Jember and the result was that employee work motivation had a significant effect on employee performance. Several other studies include:(Mayangsari et al. 2020), (Hardianto et al. 2020), (Samah et al. 2019), (Adha, Qomariah, and Hafidzi 2019), (Solikah, Setyowati, and Sanosra 2016), (Hermawan 2015), (Bentar, Purbangkoro, and Prihartini 2017), (Fachreza, Musnadi, and Majid 2014), (Sumowo 2017), (Hanafi and Abadi 2018), (Qomariah and Setyowati 2020), (Lopes 2016), (Komaling, Adolfina, and Untu 2016), (Sya'roni, Herlambang, and Cahyono 2018), (Firdaus, Widyanti, and Khuzaini 2017).

The next factor that can improve employee performance is leadership style. Leadership style is a person's ability to control the organization (Handoko 2010). A person who is appointed as a leader must be able to control group members in an organization (Mu'ah 2002). Various kinds of person's behavior in controlling the organization they lead. An organization can improve the performance of its employees depending also on how the leadership in the organization controls it. A good leader is a leader who can invite his or her bills to perform well. Research on the relationship between leadership style and employee performance has been carried out and published in several scientific journals.

Research (Hafifi, Qomariah, and Arifin 2018) was conducted 
on employees of the production division at PT. Mitratani Dua Tujuh Jember, amounting to 56 employees and the results of his research were that the work environment, leadership style, and job training could improve the performance of the production division employees at PT. Mitratani Dua Tujuh Jember. (Prijono et al., 2019) conducted research on SKPD (Regional Government Work Unit) Employees in the Inspectorate of Jember Regency with 210 respondents as respondents. The result is that competence, integrity and leadership have no significant effect on the performance of SKPD employees in Jember Regency. (Qomariah, 2012) conducted research on lecturers at PTS in Jember Regency with a sample of 110 lecturers and the result was that organizational culture, leadership and organizational commitment had a positive impact on lecturer performance. (Andriani et al., 2018) conducted research on Palembang State Vocational High School teachers with a population of 790 teachers and who were sampled as many as 193 teachers and the results of the research were that transformational leadership and work motivation had an impact on teacher performance. (Listiani et al., 2020) conducted research on employees of PT. Wahana Persada Lampung, Auto 2000 Raden Intan and PT. Honda Lampung Raya, where each company took a sample of 40 employees so there were 120 respondents, and the results of the research were that leadership style had a significant influence on employee performance. (Sugiyatmi et al., 2016) conducted research on employees of PT. Bina San Prima is a milk distributor with a sample size of 35 employees and the results of its research indicate that there is a positive influence between leadership on employee performance. Research (Ayu \& Suprayetno, 2005) at PT. Pei Hai International Wiratama Indonesia, the result is that leadership has an impact on company performance. Research (Vidianingtyas \& Putri, 2014) on employees at a Catering Service Company in the Special Region of Yogyakarta shows that leadership has a positive impact on employee performance. (Ayuningtyas \& Whidya Utami, 2019) conducted research at the Foundation of the Prosperous Education Management Association in Surabaya with 119 respondents, and the results were leadership style, compensation and job satisfaction significantly affected by the employee performance. (Wiranata, 2011) conducted research at CV. The result shows that leadership contributes $53.29 \%$ to employee performance. Research (Jayanti \& Wati, 2014) at PT. Fastrata Buana Pulogadung Branch with a sample of 187 employees, the result is that there is a positive influence between leadership style and employee performance. (Abbas et al., 2020) conducted a study on 323 respondents working in higher education participating, the result was that servant leadership is a proactive predictor of employee performance and the relationship is strengthened when tested with religiosity. (Kurniawati \& Tobing, 2019) conducted research on 224 lecturers at Politeknik Negeri Jember, whose results were motivation, working environment, and self-leadership which gave a significant effect on lecturer performance. (Sulistyo, 2009) conducted a study with the theme of spiritual leadership, organizational communication, work satisfaction, organizational commitment and work performance with 100 officials at Telkom Company, the result was the spiritual leadership has no influence on work satisfaction and work performance. Several other studies include: (Riyadi 2020), (Abbas et al.
2020), (Hadiana and Maya Sari 2019), (Areiqat et al. 2020), (Ishak, Mei, and Majid 2019), (Dolphina 2012), (Wardani, Cahyono, and Herlambang, Toni Qomariah 2017), (Bentar et al. 2017), (Hendrawan and Budiartha 2018), (Sya'roni et al. 2018), (Priyono, Qomariah, and Winahyu 2018).

The third factor in research that is thought to improve employee performance is work culture. Work culture is a habit that is applied by an organization to achieve its planned goals (Davis and Newstorm 2008). Work culture can also be said to be a habit that is done repeatedly in an organization that can change a person's habits for the better (Nawawi 2011). Good habits in an organization, if applied by employees, can be completed in a timely manner. For example, the disciplinary habits applied by the organization will make employees come regularly to complete their duties. Many studies link a person's work culture with employee performance.

(Wambugu 2014) conducted research on organizational culture that is associated with employee performance in Wärtsilä - Kipevu II Power Plant employees, which results in organizational values has a more significant effect on employee's job performance. (Rantesalu, Mus, and Arifin 2017) conducted research on competence, motivation, organizational culture and employee performance at the Institute of Education and Training of South Sulawesi province with a population of 513 employees and a sample of 224 employees obtained by the Slovin formula, the results of their research are that there is an effect of competency and organizational culture on performance. Research (Ojo 2009) on the Nigerian banking industry with the theme of corporate culture and Employee job performance, the results were a large number of respondents $(57.7 \%)$ strongly agree that corporate culture has an effect on employee job performance. (Manggis et al., 2018) conducted research on career development, organizational culture, employee performance at Cooperation in Denpasar Village with a sample of 33 cooperatives with the total number of employees is 338 employees and the result is that organizational culture variables have an impact on employee performance. (Saban et al. 2020) conducted a study with the theme of Islamic work ethics, competencies, compensation, work culture, job satisfaction and employee performance among employees of Four Star Hotels in South Sulawesi with a population of 2,491 hotel employees with a sample of 345 , the results were is that work culture has an impact on hotel employee performance. (Giri et al. 2011) conducted research on the effect of organizational culture and organizational commitment to job involvement, knowledge sharing, and employee performance on Regional Telecommunications Employees Of PT. Telkom East Nusa Tenggara Province, Indonesia and the result was that the organizational significant effect on employee performance.

Tegalsari Public Health Center, Banyuwangi Regency is one of the Level One Health Facilities which also took part in providing assistance for the healing and safety of patients during this and during the Covid 19 Pandemic period. During the Covid 19 pandemic, every health facility, including the Tegalsari Banyuwangi Community Health Center, was required to perform even better. The performance of this Puskesmas depends on the performance of the employee like doctors and nurses who work at the Puskesmas. Nurses are one 
of the most influential professionals with the highest number of direct contact with patients, when compared to other health workers. This condition requires nurses to be able to actively participate in reporting any incidents that occur against patients to the unit leader. Thus the performance of nurses must continue to be improved so that they can provide services to patients who come for treatment and have their health checked. From the explanation in the background and also previous research that has been conducted by several researchers, the problem formulation in this research is how to improve the performance of employee based on work motivation, leadership style and work culture at Tegalsari Health Center Banyuwangi. While the purpose of this study was to determine the impact of work motivation, leadership style and work culture on the performance of employee at Tegalsari Health Center Banyuwangi.

\section{RESEARCH METHODS}

This research is a causality research which aims to determine the effect of independent variables on the dependent variable. There are independent variables in this study are work motivation, leadership style and work culture, while the dependent variable is the employee performance. The population in this study were all employee and room leaders at Tegalsari Banyuwangi Health Center, totaling 75 people. The total population is used as a research sample, so this research is also called census research.

Validity and reliability tests are used to test whether the measuring instrument in the form of a questionnaire is valid and reliable, so that it can be used for further research (Ghozali 2011). To determine the effect of motivation, leadership style and work culture on nurse performance, multiple regression analysis techniques are used (Sekaran 2006) with the following regression formula: $\mathrm{Y}=\mathrm{a}+\mathrm{b} 1 \mathrm{X} 1+\mathrm{b} 2 \mathrm{X} 2+\mathrm{b} 3$ $\mathrm{X} 3+\mathrm{e}$. The classical assumption test is carried out to determine whether the linear regression used can be a good and unbiased assessment(Sugiyono 2013).

\section{RESULTS AND DISCUSSION}

\section{Descriptive Statistics Results}

The results of descriptive statistics based on the age of the respondents were 75 respondents, so as many as 25 respondents were 24-34 years old with a percentage of $33.3 \%, 34$ respondents were 35-34 years old with a percentage of $45.4 \%$, 16 respondents were aged 45 and above has a percentage of $21.3 \%$. So it can be seen that some employees who work at Tegalsari Health Center are at the age of 35-44 years with a percentage of $45.4 \%$. The results of descriptive statistics for respondents with gender indicators showed that 56 respondents $(75 \%)$ were female respondents and the rest were male respondents.

\section{Validity Test and Reliability Test}

The results of the validity test show that all indicators used in this study have a calculated r-value greater than the r-table value, so it can be said that the measuring instrument used is valid. Reliability test results show that the Cronbach alpha value for all variables is above the required alpha value so that the measuring instrument in this study is declared reliable.

\section{Multiple Linear Regression Test Results}

Multiple linear regression analysis to measure the strength of the relationship between two or more variables, also shows the direction of the relationship between the dependent variable and the independent variable (Ghozali 2011). The results of multiple linear regression analysis produce the following regression equation: $\mathrm{Y}=17.821+0.177 \mathrm{X} 1+0.282 \mathrm{X} 2-$ $0.027 \mathrm{X} 3+\mathrm{e}$.

Table 1. Reliability Test Results

\begin{tabular}{|c|c|c|c|}
\hline Variable & $\begin{array}{c}\text { Cronbach } \\
\text { Alpa }\end{array}$ & $\begin{array}{c}\text { Reliability } \\
\text { Value }\end{array}$ & Information \\
\hline Motivation (X1) & 0,60 & 0,673 & Reliable \\
\hline $\begin{array}{c}\text { Leadership Style } \\
\text { (X2) }\end{array}$ & 0,60 & 0,690 & Reliable \\
\hline Work Culture (X3) & 0,60 & 0,724 & Reliable \\
\hline $\begin{array}{c}\text { Employee } \\
\text { Performance (Y) }\end{array}$ & 0,60 & 0,739 & Reliable \\
\hline
\end{tabular}

Table 2. Results of Multiple Linear Regression Analysis

\begin{tabular}{|c|c|c|c|c|c|}
\hline \multirow{2}{*}{ Model } & \multicolumn{2}{|c|}{$\begin{array}{c}\text { Unstandardized } \\
\text { Coefficients }\end{array}$} & $\begin{array}{c}\text { Standardized } \\
\text { Coefficients }\end{array}$ & \multirow{2}{*}{ Sig. } \\
\cline { 2 - 6 } & $\mathbf{B}$ & $\begin{array}{c}\text { Std. } \\
\text { Error }\end{array}$ & Beta & & \\
\hline (Constant) & 17,821 & 8,410 & & 2,119 &, 038 \\
\hline Motivation &, 177 &, 103 &, 190 & 1,727 &, 089 \\
\hline Leadership &, 282 &, 101 &, 329 & 2,804 &, 007 \\
\hline Work Culture &,- 027 &, 105 &,- 030 &,- 256 &, 799 \\
\hline
\end{tabular}

\section{Discussion}

The results of statistical calculations show that $t$ count of 1.727 from the motivation variable has a significance value of $0.089>0.05(=5 \%)$, so Ho is accepted and $\mathrm{H} 1$ is rejected. This means that the hypothesis that motivation has a positive and significant effect on the performance of Tegalsari Health Center employees is rejected. Which means that if the motivation in this study suggests that the variable or motivation factor has an influence on the performance of employees at the Tegalasri Health Center but it has a significant effect, it is not proven that motivation is one of the important things considered by employees to improve employee performance. Motivation is a condition in which the effort and willpower of an employee can produce results in the form of productivity, dependence or other creative work behavior. Hasibuan (2003) states that work motivation is the provision of a driving force that creates excitement for someone's work so that they are willing to work together, work effectively and be integrated with all their efforts to achieve satisfaction. The important driving factor that causes humans to work is the existence of 
wholeness that must be fulfilled.

The results of the calculation of the leadership style variable that have been carried out obtained a significance level of 2.804 from the leadership style variable which has a significance value of $0.007<0.05(=5 \%)$, so Ho is rejected and $\mathrm{H} 1$ is accepted. Which means the hypothesis which states that leadership style has a positive and significant effect on employee performance at Tegalsari Health Center is accepted. This statistical test proves that there is a positive and significant influence of leadership style on employee performance. This means that the leadership style of the Head of the Puskesmas is always ready to make decisions in implementing openness, freedom of improvement, and effective work discipline.

The third hypothesis states that work culture has no significant effect on employee performance. By being able to count through the calculation, it shows that $t$ count of -0.256 of this work culture variable has a significance value of $0.779>0.05$ $(5 \% /)$ so Ho is accepted and H1 is rejected. This affects a work culture that does not affect the performance of nurses because supervision and service, which are the most important indicators, cannot function properly as the obligations of puskesmas employees which they should have done as employees there by following the applicable provisions or SOPs, this is a habit. that has been and must be done by employees so that it does not affect their performance.

\section{CONCLUSIONS AND RECOMMENDATIONS}

The results of the study proved that there was no influence of the motivation variable on the employee performance. The work motivation of the employee is always maintained so that the service to the patient is always maximal. Employee at Tegalsari Health Center Banyuwangi, although motivation does not affect the performance of employee. This is because the motivation to work better is embedded in the minds of the nurses so that their performance can increase. The hypothesis which states that leadership has an effect on employee performance is accepted. This proves that the leadership at Puskesmas Tegalsari Banyuwangi has succeeded in improving the performance of nurses. Therefore, leaders in this health facility must continue to maintain the leadership style that has been applied so far so that the performance of employee continues to increase. In this study, it shows that the work culture variable does not have a positive and significant effect on the performance of nurses at Tegalsari Health Center Banyuwangi. Therefore, nurses at the health center must be more maximal in carrying out their obligations and responsibilities in serving patients at the puskesmas by implementing better SOPs so that the performance of puskesmas staff will increase and the supervision and service will be maximized.

Based on the respondent's assessment of motivation is good, to maintain business motivation to maintain employee performance can be done by continuing to apply work discipline, environment, and quality service so that an employee's performance is better. Based on the respondent's assessment of the leadership style is good, it would be even better if the application of openness, freedom of improvement and a more consistent work discipline will improve employee performance. Based on the respondent's assessment, work culture is good, it can also be measured from the high level of motivation and leadership style that will affect the work culture so as to create good employee performance so that employee performance will increase and optimize.

In this study, there are research limitations such as the limited number of respondents, the data that is still not good in the heteroscedasticity test even though the dots spread above and below the number 0 on the $\mathrm{Y}$ axis but the dots still have not spread optimally, the variables are less varied and the analysis is still simple. So it is suggested for further researchers to: 1) conduct research by increasing the number of respondents in the study and using the latest analysis tools so that there are breakthroughs that innovate and add quality to the thesis, 2) conduct research using varied variables so that they do not only use quality product, promotion strategy and brand image but also testing other variables such as loyalty, product attributes, diferencial strategy and so on.

\section{REFERENCES}

Abbas, Ansar, Muhammad Saud, Indrianawati Usman, and Dian Ekowati. 2020. "Servant Leadership and Religiosity: An Indicator of Employee Performance in the Education Sector." International Journal of Innovation, Creativity and Change 13(4):391-409.

Adha, Risky Nur, Nurul Qomariah, and Achmad Hasan Hafidzi. 2019. "Pengaruh Motivasi Kerja, Lingkungan Kerja, Budaya Kerja Terhadap Kinerja Karyawan Dinas Sosial Kabupaten Jember." Jurnal Penelitian IPTEKS $4(1): 47$.

Ahmad, Muhammad Arifin, Bachri Talib, and Muhammad Arif Tiro. 2014. "The Influence Of Certification Toward Work Motivation, Job Satisfaction And Performance Of State High Schools Guidance And Counseling Teacher In South Sulawesi." International Journal of Scientific and Technology Research 3(8):386-94.

Anon. 2019. "Https://Www.Validnews.Id/InfografisPerkembangan-Fasilitas-Pelayanan-Kesehatan-DiIndonesia--2014-2018--Zf."

Anon. 2020. "Https://Prfmnews.PikiranRakyat.Com/Nasional/Pr-13747614/Update-16-

September-2020-Jumlah-Positif-Corona-Di-IndonesiaBertambah-3963-Kasus."

Ardianti, Febry Erfin, Nurul Qomariah, and Yohanes Gunawan Wibowo. 2018. "PENGARUH MOTIVASI KERJA, KOMPENSASI DAN LINGKUNGAN KERJA TERHADAP KEPUASAN KERJA KARYAWAN (Studi Kasus Pada PT. Sumber Alam Santoso Pratama Karangsari Banyuwangi) EFFECT." Jurnal Sains Manajemen \& Bisnis Indonesia 8(1):13-31.

Areiqat, Ahmad Yousef, Yacoub Hamdan, Ahmad M. A. Zamil, Omar Horani, and Abeer Fayez Al-Khoury. 2020. "Culture and Leadership Are Simply Two Sides of the Same Coin." International Journal of Innovation, 
International Journal of Engineering Research and Technology. ISSN 0974-3154, Volume 13, Number 9 (2020), pp. 2511-2518

(C) International Research Publication House. https://dx.doi.org/10.37624/IJERT/13.9.2020.2511-2518

Creativity and Change 13(4):123-47.

Azhad, M. Naely, Anwar, and Nurul Qomariah. 2015. Manajemen Sumber Daya Manusia. Jember: Cahaya Ilmu.

Basalamah, Muhammad Syafi. 2017. "The Influence Of Motivation, Competence And Individual Characteristics On Performance Clerk (The Study) In The City Of Makassar." International Journal of Scientific \& Technology Research 6(12):148-53.

Bentar, Aidin, Murdijanto Purbangkoro, and Dewi Prihartini. 2017. "ANALISIS PENGARUH KEPEMIMPINAN, MOTIVASI, DISIPLIN KERJA DAN LINGKUNGAN KERJA TERHADAP KINERJA KARYAWAN TAMAN BOTANI SUKORAMBI ( TBS ) JEMBER." Jurnal Manajemen Dan Bisnis Indonesia 3(1):1-17.

Davis, Keith and John W. Newstorm. 2008. Perilaku Dalam Organisasi. Jakarta: Erlangga.

Dolphina, Erlin. 2012. "Pengaruh Motivasi, Kepemimpinan Dan Budaya Kerja Terhadap Kepuasan Kerja Karyawan Serta Dampaknya Pada Kinerja Perusahaan." Seminar Nasional Teknologi Informasi \& Komunikasi Terapan 2012 (Semantik 2012) 2012(Semantik):1-7.

Fachreza, Said Musnadi, and M. Shabri Abd Majid. 2014. "Pengaruh Motivasi Kerja, Lingkungan Kerja, Dan Budaya Organisasi Terhadap Kinerja Karyawan Dan Dampaknya Pada Kinerja Bank Aceh Syariah Di Kota Banda Aceh." Jurnal Magister Manajemen V(1):42-56.

Firdaus, Rahmi Widyanti, and Khuzaini. 2017. "PENGARUH MOTIVASI DAN LINGKUNGAN KERJA TERHADAP KINERJA KARYAWAN." Jurnal Komunikasi, Bisnis, Dan Manajemen 4(1):86-98.

Ghozali, Imam. 2011. Aplikasi Analsiis Multivariate Dengan Program SPSS. Semarang: BP Universitas Diponegoro.

Giri, Endang Eviline, Umar Nimran, Djamhur Hamid, Al Musadieq, and Mochammad Al Musadieq. 2011. "The Effect of Organizational Culture and Organizational Commitment to Job Involvement, Knowledge Sharing, and Employee Performance: A Study on Regional Telecommunications Employees of PT Telkom, East Nusa Tenggara Province, Indonesia." International Journal of Management and Administrative Sciences 3(04):20-33.

Hadiana, R. Nana and Nur Zeina Maya Sari. 2019. "The Influence of Transformational Leadhership and Commitment Organization Implications for Performance Employee State Civil Apparatus (Asn Bandung Indonesian)." International Journal of Scientific and Technology Research 8(1):8-13.

Hafifi, Muhammad Adip, Nurul Qomariah, and Anwar Arifin. 2018. "PENINGKATAN KINERJA BERBASIS LINGKUNGAN KERJA, GAYA KEPEMIMPINAN, DAN PELATIHAN KERJA PADA KARYAWAN BAGIAN PRODUKSI PT. MITRATANI DUA TUJUH JEMBER." Jurnal Manajemen Dan Bisnis Indonesia Vol.
2(1):212-14.

Hanafi, Chairul and Sanosra. Abadi. 2018. "PENGARUH MOTIVASI KERJA, IKLIM ORGANISASI TERHADAP KOMITMEN ORGANISASI DAN KINERJA DOSEN PENDIDIKAN GURU PENDIDIKAN ANAK USIA DINI IKIP PGRI JEMBER.” JSMBI ( Jurnal Sains Manajemen Dan Bisnis Indonesia ) 8(1):94-111.

Handoko, Hani. 2010. Manajemen Personalia Sumber Daya Manusia. Edisi Ke 2.

Hardianto, Ari, Sukisno S. Riadi, Sri Mintarti, Sugeng Hariyadi, Martinus Robert Hutauruk, and Imam Ghozali. 2020. "The Impact Of Human Relations On Motivation And Performance And The Role Of Entrepreneur Mediators In Bank Mandiri (Persero) Tbk East Kalimantan Kaltara Areas." International Journal of Scientific and Technology Research 9(3):1238-43.

Hendrawan, Putu Ryan and I. Ketut Budiartha. 2018. "Pengaruh Integritas, Independensi, Dan Gaya Kepemimpinan Transformasional Pada Kinerja Auditor Inspektorat Kota Denpasar.” E-Jurnal Akuntansi 24:1359.

Hendrawijaya, A. T., N. Imsiyah, and D. T. Indrianti. 2019. "Public Servants Characteristics and Their Perception on Motivation and Performance." International Journal of Scientific and Technology Research 8(6):78-81.

Hermawan, Haris. 2015. "PENGARUH MOTIVASI KERJA, KOMPENSASI FINANSIAL DAN KOMPENSASI NON FINANSIAL TERHADAP PRESTASI KERJA KARYAWAN PADA PERUSAHAAN BINTANG MULIA HOTEL \& RESTO JEMBER." Jurnal Manajemen Dan Bisnis Indonesia 1(2):143-61.

Hidayah, Tamriatin and Diana Sulianti K. Tobing. 2018. "The Influence of Job Satisfaction, Motivation, and Organizational Commitment to Employee Performance." International Journal of Scientific and Technology Research 7(7):122-27.

Ishak, Mohd Nadzri, Tang Swee Mei, and Abdul Halim Abdul Majid. 2019. "An Effect of Authentic Leadership as Moderator in Teachers" Performance Appraisal Satisfaction." International Journal of Scientific and Technology Research 8(12):1993-96.

Istanti, Enny, Achmad Daengs Gs, Fadjar Budianto, Indah Noviandari, and Ruchan Sanusi. 2020. "The Influences of Motivation, Work Milieu, and Organizational Commitment on Teacher Performance in MTS Negeri 4 (Public Islamic School), Surabaya East Java." International Journal of Innovation, Creativity and Change 13(2):629-42.

Komaling, Helena Joan, Adolfina, and Victoria Untu. 2016. "The Influences Of Recruitment, Motivation, And Work Environment To The Employee Performance Of PT . Bank Rakyat." Jurnal Berkala Ilmiah Efisiensi 16(01):738-49.

Kurniawan, Resa Adji, Nurul Qomariah, and Pawestri 
International Journal of Engineering Research and Technology. ISSN 0974-3154, Volume 13, Number 9 (2020), pp. 2511-2518

(C) International Research Publication House. https://dx.doi.org/10.37624/IJERT/13.9.2020.2511-2518

Winahyu. 2019. "Dampak Organizationlal Citizenship Behavior , Motivasi." Jurnal Penelitian IPTEKS 4(2):148-60.

Lopes, Eusebio da Costa. 2016. "Pengaruh Motivasi Terhadap Disiplin Kerja Dan Kinerja Pegawai Pada Direccao Geral Dos Servicos Corporativos Ministerio Das Obras Publicas Dili Timor-Leste." Jurnal Sains Manajemen \& Bisnis Indonesia 6(2):158-69.

Mayangsari, Lidia, Triani Restianti, Jumadil Saputra, and Raden Aswin Rahadi. 2020. "The Relationship between Self-Employed Motivation and Individual Work Performance among Online Drivers in West Java, Indonesia." International Journal of Innovation, Creativity and Change 13(3):513-30.

Mu'ah, Mu'ah. 2002. Manajemen Sumber Daya Manusia. Jakarta: Grasindo.

Nawawi, Hadari. 2011. Manajemen Sumber Daya Manusia: Untuk Bisnis Yang Kompetitif. Yogyakarta: Gajah Mada University Press.

Ojo, Olu. 2009. "Impact Assessment Of Corporate Culture On Employee Job Performance." Business Intelligence Journal 2(2):388-97.

Permana, Angrian, M. Havidz Aima, Eny Ariyanto, and Adi Nurmahdi. 2019. "The Effect of Leadership Style, Motivation and Discipline of Employee Performance with Understanding of Islamic Work Ethics." International Journal of Scientific and Technology Research 8(8):1098-1106.

Priyono, Bayu Hendro, Nurul Qomariah, and Pawestri Winahyu. 2018. "PENGARUH GAYA KEPEMIMPINAN, MOTIVASI GURU DAN LINGKUNGAN KERJA FISIK TERHADAP KINERJA GURU SMAN 1 TANGGUL JEMBER." Jurnal Manajemen Dan Bisnis Indonesia 4(2):144-60.

Priyono, Bayu Hendro, Nurul Qomariah, and Pawestri Winahyu. 2018. "PENGARUH GAYA KEPEMIMPINAN, MOTIVASI GURU DAN LINGKUNGAN KERJA FISIK TERHADAP KINERJA GURU SMAN 1 TANGGUL JEMBER." JURNAL MANAJEMEN DAN BISNIS INDONESIA 4(2):144.

Qomariah, Nurul and Trias Setyowati. 2020. "The Role of Emotional Intelligence, Spiritual Intelligence And Work Motivation In Improving The Performance of Hotel Employees." International Journal of Economics and Management Studies 7(6):112-18.

Rantesalu, Agustina, Abdul Rahman Mus, and Zaenal Arifin. 2017. "The Effect of Competence, Motivation and Organizational Culture on Employee Performance: The Mediating Role of Organizational Commitment." Quest Journals Journal of Research in Business and Management 4(9):8-14.

Riyadi, Slamet. 2020. "The Influence of Leadership Style , Individual Characteristics and Organisational Climate on Work Motivation , Job Satisfaction and Performance."
International Journal of Innovation, Creativity and Change 13(7):662-77.

Ruky, Achmad S. 2006. Sistem Manajemen Kinerja. Jakarta: Gramedia Pustaka Utama.

Saban, Darwis, Salim Basalamah, Achmad Gani, and Zainuddin Rahman. 2020. "Impact Of Islamic Work Ethics, Competencies, Compensation, Work Culture On Job Satisfaction And Employee Performance: The Case Of Four Star Hotels." European Journal of Business and Management Research 5(1):1-8.

Samah, Irza Hanie Abu, Abdul Shukor Shamsuddin, Intan Maizura Abd Rashid, and Mohammad Harith Amlus. 2019. "Mediating Effect of Self-Satisfaction, Intrinsic Motivation and Performance. A Study on Malaysian Archers." International Journal of Scientific and Technology Research 8(12):2981-84.

Sari, Winda, Nurul Qomariah, and Trias Setyowati. 2020. "The Role of Emotional Intelligence, Spiritual Intelligence And Work Motivation In Improving The Performance of Hotel Employees." International Journal of Economics and Management Studies 7(6):112-18.

Sekaran, Uma. 2006. Metode Penelitian Untuk Bisnis. Jakarta: Salemba Empat.

Soebyakto, Bambang Bemby, Agustina Hanafi, and Erwin Rakasiwih. 2019. "Effect Of Training, Motivation, And Job Satisfaction On Employee Performance At Pt Techwin Bkt." International Journal of Scientific and Technology Research 8(12).

Solikah, Ita, Trias Setyowati, and Abadi Sanosra. 2016. "PENGARUH REWARD , PUNISHMENT DAN MOTIVASI KERJA TERHADAP PRODUKTIVITAS KERJA KARYAWAN PADA PTPN XII ( Persero ) KEBUN JATIRONO KALIBARU." Manajemen Dan Bisnis Indonesia 2(1):91-105.

Sugiyono. 2013. Metode Penelitian Pendidikan Pendekatan Kuantitatif, Kualitatif, Dan R\&D. Bandung: Alfabeta.

Sumowo, Seno. 2017. “ANALISIS DISIPLIN KERJA DAN MOTIVASI KERJA TERHADAP PRESTASI KERJA KARYAWAN PADA LAVA - LAVA HOSTEL DAN RESTO PROBOLINGGO Seno Sumowo Fakultas Ekonomi Universitas Muhammadiyah Jember Email : Senosumowo@unmuhjember.Ac.Id PENDAHULUAN Di Dalam Kehidupan Seha." Jurnal Penelitian IPTEKS (2):49-60.

Sutrisno, Edy. 2015. Manajemen Sumber Daya Manusia(Cetakan Ke Tujuh). Jakarta: Salemba Empat.

Sya'roni, Toni Herlambang, and Dwi Cahyono. 2018. "DAMPAK MOTIVASI, DISIPLIN KERJA DAN KEPEMIMPINAN KEPALA SEKOLAH TERHADAP KINERJA GURU." Jurnal Sains Manajemen \& Bisnis Indonesia 8(2):131-47.

Wambugu, Lydiah Wairimu. 2014. "Effects of Organizational Culture on Employee Performance (Case Study of Wartsila -Kipevu Ii Power Plant)." European Journal of 
International Journal of Engineering Research and Technology. ISSN 0974-3154, Volume 13, Number 9 (2020), pp. 2511-2518

(c) International Research Publication House. https://dx.doi.org/10.37624/IJERT/13.9.2020.2511-2518

Business and ManagementOnline) 6(32):80-93.

Wardani, Dian Kusuma, Dwi Cahyono, and Nurul Herlambang, Toni Qomariah. 2017. "PENGARUH GAYA KEPEMIMPINAN TERHADAP KEPUASAN KERJA DAN KINERJA DENGAN KOMITMEN ORGANISASI SEBAGAI VARIABEL INTERVENING DI RUMAH SAKIT ISLAM LUMAJANG EFFECT." Jurnal Sains Manajemen \& Bisnis Indonesia 7(2):20831. 